Provided for non-commercial research and education use. Not for reproduction, distribution or commercial use.

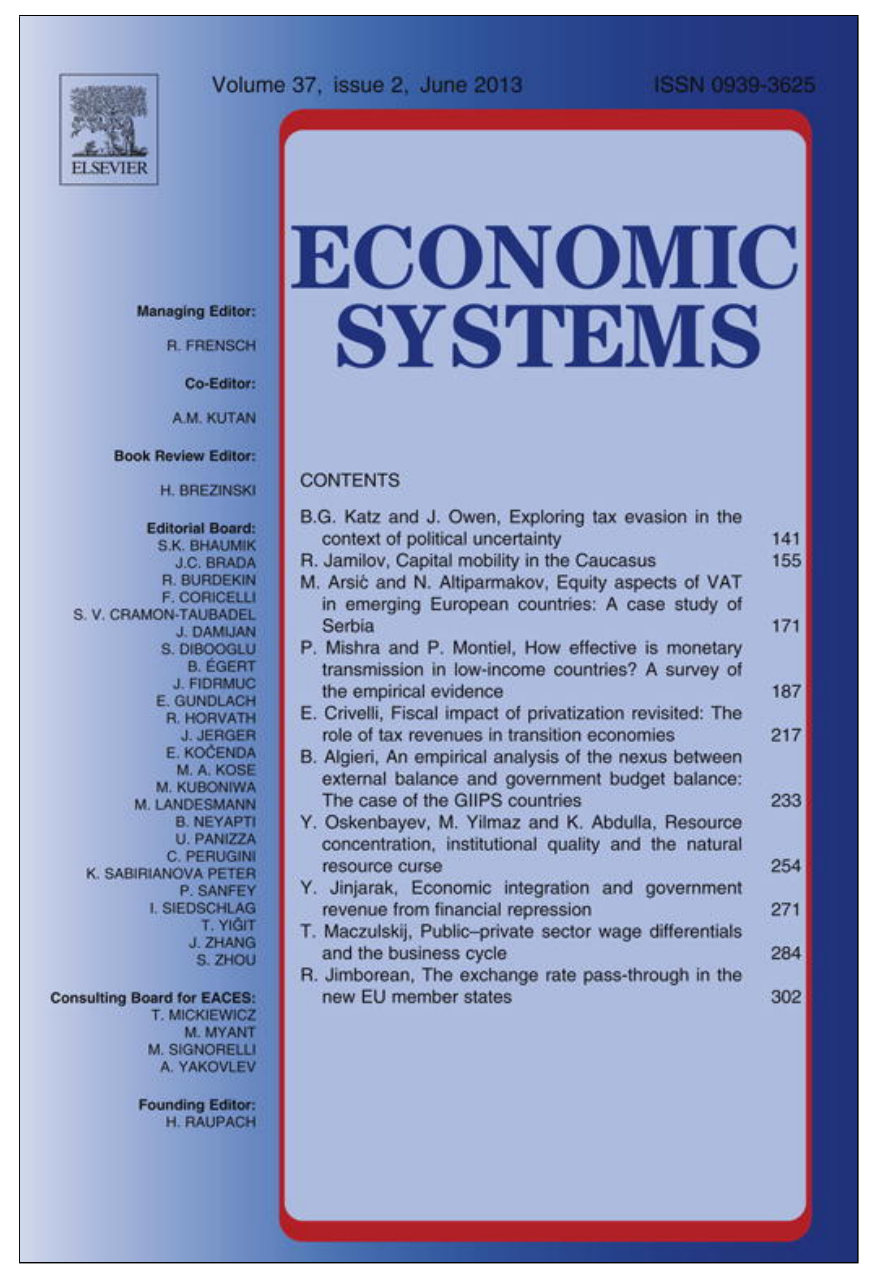

This article appeared in a journal published by Elsevier. The attached copy is furnished to the author for internal non-commercial research and education use, including for instruction at the authors institution and sharing with colleagues.

Other uses, including reproduction and distribution, or selling or licensing copies, or posting to personal, institutional or third party websites are prohibited.

In most cases authors are permitted to post their version of the article (e.g. in Word or Tex form) to their personal website or institutional repository. Authors requiring further information regarding Elsevier's archiving and manuscript policies are encouraged to visit:

http://www.elsevier.com/authorsrights 


\title{
Economic integration and government revenue from financial repression
}

\author{
Yothin Jinjarak ${ }^{*}$ \\ Department of Financial and Management Studies, School of Oriental and African Studies, \\ University of London, WC1HOXG, United Kingdom
}

\section{A R T I C L E I N F O}

\section{Article history:}

Received 28 October 2011

Received in revised form 4 October 2012

Accepted 24 October 2012

\section{JEL classification:}

F36

H63

P11

Keywords:

Financial repression

Globalization

Government debt

\begin{abstract}
A B S T R A C T
We study a relationship between economic openness via financial and trade integration and government revenue from financial repression. An implicit budgetary saving, the financial repression revenue, as measured by the stock of government domestic debt multiplied by the difference between effective foreign and domestic interest rate, has declined significantly from the 1980s into the 2000s across the upper-income, the middle-income, and the lowincome developing countries. While we find that both the financial and trade openness have a negative association with the financial repression revenue in the panel of countries, the effect of financial openness is stronger and the empirical correlations depend on the quality of governmental and budgetary management.
\end{abstract}

(c) 2013 Elsevier B.V. All rights reserved.

\section{Introduction}

The financial repression revenue is the 'easy-to-tax' revenue source of developing country governments, commonly used along with import/export tariffs and seigniorage. A channel of this implicit taxation relies on the imposition of governmental controls on international capital flows and domestic financial intermediaries, thereby increasing a wedge between the effective foreign rate and domestic rate of interest payments on public debt. Essentially, the resultant wedge between the foreign and domestic interest rates is a tax on financial transactions, providing in turn a subsidy or saving on interest liabilities to the government.

\footnotetext{
* Tel.: +4402078984352.

E-mail address: yj5@soas.ac.uk.
} 
How prevalent is the government revenue from financial repression? In the 1970s, this revenue was as high as 39\% of total revenue in Mexico and 22\% in India; see Giovannini and De Melo (1993). Since the 1980s, the global economy has embraced policy reforms towards more trade and financial integration, liberalisation and stabilisation. These reforms have influenced a common fiscal denominator, in the process reducing the gap between the foreign and domestic interest rate, and hence the government revenue from financial repression. In Table 1 we offer an update of the financial repression revenue for the 1990s and 2000s. Notably, in the sample of 62 countries, the average of financial repression revenue to GDP is $4 \%$, ranging, for instance, from $2.6 \%$ in Mexico to $6.2 \%$ in Argentina.

The mechanism in which economic integration affects revenue from financial repression is operating through the reduction of an existing gap between foreign and domestic interest rates. The theoretical argument for the association between economic integration and financial repression revenue suggests that financial openness is the main and direct channel. The financial openness enhances the mobility of resources and allows risk sharing between savers and investors across borders. This in turn should impose discipline on the fiscal and financial policies so that the ability of the public sector to borrow at artificially low interest rates domestically is constrained by the international capital markets that are now financially opened to the local savers and investors (Kletzer, 2004). Alternatively, trade channel may also be instrumental in reducing the financial repression revenue. Aizenman $(2004,2008)$ outlines a theoretical model accounting for a model accounting for the endogenous linkages between trade openness (i.e. declining tariffs and non-tariff barriers) and financial openness (i.e. lowering capital controls and increasing capital flows). In the model, greater trade openness increases the effective cost of fiscally enforcing import over-invoicing/ export under-invoicing, the illicit capital movement that facilitates financial repression, which in turn reducing the usefulness of financial repression as an implicit tax and enhancing policy reform towards the financial openness. ${ }^{1}$ The association between financial repression, trade and financial openness is therefore an empirical question that provides the hypothesis of our study.

This study adds to strand of literature that focuses on the intertwining of public finance and international factor movements. Earlier studies on the government revenue from financial repression in an international context include Reinhart and Sbrancia (2011), Kletzer (2004), Serven and Perry (2005), Demetriades and Luintel (1997), Dooley (1996), Giovannini and De Melo (1993), Cukierman et al. (1992), and Diaz Alejandro (1985). By and large, these studies document the extent of financial repression in the periods following the financial turbulences in the 1970s and prior to the 2000s in a small set of countries, some of which are country specific. For instance, Serven and Perry find in the case of Argentina that from the beginning of its major trade and financial opening in 1991 to macroeconomic collapse in 2002, the cost of refinancing public debt had been on the rise, with the implicit interest rate increased from 5\% in 1993 to 8\% in 2001, together with the steady growth of public debt stock further deteriorating repayment capacity of the Argentine government. Reinhart and Sbrancia find in that the financial repression is effective when accompanied by a steady rise of inflation during 1945-1980 for the advanced economies. Our study contributes to the literature by expanding both the countries and years coverage, measuring directly the financial repression revenue from several data sources, as well as formally testing the relationship between trade and financial openness, and the financial repression revenue in various specifications.

\section{Estimation}

The hypothesis of our testing is whether the ongoing economic integration has influenced the adjustment of financial repression revenue across countries. As shown in Aizenman $(2004,2008)$, in the presence of diminishing marginal efficacy of tax enforcement and costly tax collection, trade openness of countries that repress their financial system could lead to financial openness, thereby affecting the cost of servicing public debt liabilities and hence the use of financial repression as an

\footnotetext{
${ }^{1}$ This consideration remains an important one in the developing countries as, for instance, the cost of tax collection is 2.2 percent of total tax revenue in Argentina, 1.3 in Bolivia, 1.6 in Brazil, and 2.0 in Ecuador, whereas it is .9 in Spain and .4 in the US; see Singh et al., 2005. While these numbers are not that large, they are non trivial.
} 
Table 1

Government revenue from financial repression. Effective foreign (domestic) interest rate is calculated as foreign (domestic) interest payments divided by the amount of foreign (domestic) debt outstanding. Financial repression tax rate [A] is the sum of the rate of currency depreciation and the difference between effective foreign and domestic interest rates [B]. The resultant financial repression revenue to GDP $[C]$ is calculated as the tax rate multiplied by domestic debt outstanding divided by GDP.

\begin{tabular}{|c|c|c|c|c|c|c|c|c|c|c|c|c|c|}
\hline & \multirow[t]{3}{*}{ Country } & \multicolumn{2}{|c|}{ Period } & \multicolumn{3}{|c|}{ Source of revenue } & & \multirow[t]{3}{*}{ Country } & \multicolumn{2}{|l|}{ Period } & \multicolumn{3}{|c|}{ Source of revenue } \\
\hline & & & & $\begin{array}{l}\text { Financial } \\
\text { repression } \\
\text { tax rate }\end{array}$ & $\begin{array}{l}\text { Effective } \\
\text { foreign } \\
\text { versus } \\
\text { domestic } \\
\text { interest rate } \\
\text { differentials }\end{array}$ & $\begin{array}{l}\text { Financial } \\
\text { repression } \\
\text { revenue } \\
\text { to GDP }\end{array}$ & & & & & $\begin{array}{l}\text { Financial } \\
\text { Repression } \\
\text { Tax Rate }\end{array}$ & $\begin{array}{l}\text { Effective foreign } \\
\text { versus domestic } \\
\text { interest rate } \\
\text { differentials }\end{array}$ & $\begin{array}{l}\text { Financial } \\
\text { repression } \\
\text { revenue } \\
\text { to GDP }\end{array}$ \\
\hline & & Start & End & {$[\mathrm{A}]$} & {$[\mathrm{B}]$} & {$[C]$} & & & Start & End & {$[\mathrm{A}]$} & [B] & {$[\mathrm{C}]$} \\
\hline 1 & Argentina*+ & 1997 & 2002 & 0.411 & 0.068 & 0.062 & 32 & Mexico*+ & 1983 & 2002 & 0.098 & -0.249 & 0.026 \\
\hline 2 & Bangladesh+ & 1991 & 2002 & 0.515 & 0.474 & -0.008 & 33 & Moldova & 1998 & 2002 & -0.020 & -0.104 & -0.002 \\
\hline 3 & Belarus & 1996 & 2001 & 1.471 & -0.095 & 0.074 & 34 & Morocco+ & 1979 & 2002 & 0.044 & -0.002 & 0.018 \\
\hline 4 & Belize & 2001 & 2002 & -0.037 & -0.037 & -0.001 & 35 & Myanmar & 1991 & 1994 & -0.007 & 0.007 & 0.000 \\
\hline 5 & Brazil*+ & 1996 & 2001 & 0.045 & -0.138 & 0.012 & 36 & Nigeria*+ & 1995 & 2002 & 0.360 & -0.076 & 0.092 \\
\hline 6 & Cameroon+ & 1985 & 1999 & 0.041 & -0.019 & 0.025 & 37 & Pakistan*+ & 1990 & 2002 & 0.047 & -0.039 & 0.032 \\
\hline 7 & Chile*+ & 1997 & 2001 & 0.125 & 0.033 & 0.013 & 38 & Panama*+ & 1994 & 2002 & 0.023 & 0.023 & 0.004 \\
\hline 8 & China+ & 1982 & 2002 & 0.083 & -0.002 & 0.002 & 39 & $\begin{array}{l}\text { Papua } \\
\text { New Guinea }\end{array}$ & 1992 & 1995 & 0.041 & -0.041 & 0.012 \\
\hline 9 & Colombia*+ & 1981 & 2002 & 0.164 & -0.023 & 0.013 & 40 & Peru+ & 2000 & 2002 & 0.030 & 0.016 & 0.003 \\
\hline 10 & Costa Rica*+ & 1991 & 2002 & 0.143 & 0.021 & 0.037 & 41 & Philippines*+ & 1996 & 2002 & 0.140 & 0.028 & 0.077 \\
\hline 11 & Croatia & 1996 & 2002 & 0.058 & -0.005 & 0.007 & 42 & Poland ${ }^{*+}$ & 1992 & 2002 & 0.034 & -0.102 & 0.008 \\
\hline 12 & Czech Republic & 1994 & 2000 & 0.043 & 0.000 & 0.005 & 43 & Romania+ & 1994 & 2002 & 0.522 & -0.045 & 0.143 \\
\hline 13 & Ecuador*+ & 1986 & 2002 & 0.429 & -0.021 & 0.047 & 44 & $\begin{array}{l}\text { Russian } \\
\text { Federation }\end{array}$ & 1994 & 2002 & 0.480 & -0.078 & 0.114 \\
\hline 14 & Egypt, Arab Rep.+ & 1988 & 2002 & 0.140 & -0.022 & 0.084 & 45 & Senegal+ & 1981 & 1989 & 0.115 & 0.056 & 0.019 \\
\hline 15 & El Salvador*+ & 2000 & 2001 & -0.027 & -0.026 & 0.000 & 46 & Sierra Leone+ & 1986 & 1994 & 0.508 & -0.315 & 0.099 \\
\hline 16 & Ethiopia+ & 1983 & 1998 & 0.083 & -0.011 & 0.031 & 47 & Slovak Republic & 1995 & 2002 & 0.013 & -0.034 & 0.007 \\
\hline 17 & Gabon+ & 1991 & 1994 & 0.205 & -0.046 & 0.080 & 48 & South Africa*+ & 1995 & 2002 & 0.214 & 0.066 & 0.083 \\
\hline 18 & Ghana+ & 1990 & 1995 & -0.041 & -0.331 & 0.004 & 49 & Sri Lanka+ & 1990 & 2002 & 0.009 & -0.070 & 0.005 \\
\hline 19 & Guatemala*+ & 1995 & 2002 & -0.052 & -0.092 & -0.003 & 50 & Tanzania+ + & 1988 & 1999 & 0.089 & -0.149 & 0.006 \\
\hline 20 & Hungary*+ & 1992 & 2001 & 0.106 & -0.040 & 0.071 & 51 & Thailand*+ & 1991 & 2002 & 0.018 & -0.031 & 0.004 \\
\hline 21 & India*+ & 1986 & 2002 & 0.075 & -0.011 & 0.042 & 52 & $\begin{array}{l}\text { Trinidad } \\
\text { and Tobago*+ }\end{array}$ & 1985 & 2002 & 0.044 & -0.016 & -0.014 \\
\hline 22 & Indonesia*+ & 1991 & 1999 & -1.012 & -1.314 & -0.015 & 53 & Tunisia+ & 1990 & 2000 & 0.025 & -0.012 & 0.006 \\
\hline 23 & Jamaica*+ & 1987 & 2002 & 0.060 & -0.108 & 0.010 & 54 & Turkey*+ & 1988 & 2002 & 0.288 & -0.387 & 0.053 \\
\hline 24 & Jordan+ & 1982 & 2002 & 0.063 & 0.020 & 0.021 & 55 & Turkmenistan & 1997 & 1998 & 0.276 & 0.050 & 0.002 \\
\hline 25 & Kazakhstan & 1995 & 2002 & 0.256 & 0.035 & 0.013 & 56 & Uganda+ & 1991 & 1992 & -0.008 & -0.636 & 0.000 \\
\hline 26 & Latvia & 2000 & 2002 & -0.039 & -0.056 & -0.002 & 57 & Ukraine & 1995 & 2002 & -5.364 & -5.991 & 0.023 \\
\hline 27 & Lebanon & 1995 & 2002 & -0.103 & -0.089 & -0.079 & 58 & Uruguay*+ & 1992 & 2002 & 0.299 & 0.050 & 0.075 \\
\hline
\end{tabular}


Table 1 (Continued)

\begin{tabular}{|c|c|c|c|c|c|c|c|c|c|c|c|c|c|}
\hline & \multirow[t]{3}{*}{ Country } & \multicolumn{2}{|c|}{ Period } & \multicolumn{3}{|c|}{ Source of revenue } & & \multirow[t]{3}{*}{ Country } & \multicolumn{2}{|l|}{ Period } & \multicolumn{3}{|c|}{ Source of revenue } \\
\hline & & \multirow[b]{2}{*}{ Start } & \multirow[b]{2}{*}{ End } & \multirow[t]{2}{*}{$\begin{array}{l}\text { Financial } \\
\text { repression } \\
\text { tax rate } \\
{[\mathrm{A}]}\end{array}$} & \multirow[t]{2}{*}{$\begin{array}{l}\text { Effective } \\
\text { foreign } \\
\text { versus } \\
\text { domestic } \\
\text { interest rate } \\
\text { differentials } \\
\text { [B] }\end{array}$} & $\begin{array}{l}\text { Financial } \\
\text { repression } \\
\text { revenue } \\
\text { to GDP }\end{array}$ & & & \multirow[b]{2}{*}{ Start } & \multirow[b]{2}{*}{ End } & \multirow[t]{2}{*}{$\begin{array}{l}\text { Financial } \\
\text { Repression } \\
\text { Tax Rate } \\
{[\mathrm{A}]}\end{array}$} & \multirow[t]{2}{*}{$\begin{array}{l}\text { Effective foreign } \\
\text { versus domestic } \\
\text { interest rate } \\
\text { differentials } \\
\text { [B] }\end{array}$} & \multirow[t]{2}{*}{$\begin{array}{l}\text { Financial } \\
\text { repression } \\
\text { revenue } \\
\text { to GDP } \\
{[C]}\end{array}$} \\
\hline & & & & & & {$[C]$} & & & & & & & \\
\hline 28 & Lithuania & 1997 & 2002 & 0.034 & 0.047 & 0.002 & 59 & Uzbekistan & 1996 & 2000 & 0.437 & -0.090 & 0.009 \\
\hline 29 & Macedonia, FYR & 1998 & 2002 & 0.065 & 0.011 & 0.013 & 60 & Venezuela, RB*+ & 1996 & 2002 & 0.252 & -0.112 & 0.023 \\
\hline 30 & Madagascar+ & 1985 & 1988 & 0.298 & 0.031 & 0.637 & 61 & Zambia+ & 1985 & 1988 & 0.512 & -0.065 & 0.252 \\
\hline 31 & Malaysia+ & 1991 & 2002 & 0.047 & 0.012 & 0.013 & 62 & Zimbabwe+ & 1991 & 2002 & 0.084 & -0.234 & 0.015 \\
\hline
\end{tabular}


implicit tax on the financial system. Trade openness is thus our main variable of interest in our estimation. As both trade openness and financial openness are typically concurrent processes with empirical linear feedback attributable to simultaneous correlations (Aizenman and Noy, 2006; see also Edwards and van Wijnbergen, 1986, and Krueger, 1998), we also examine how the degree of capital mobility affects the financial repression revenue as a robustness check.

Since many of the trade and financial reforms were soon interrupted by vulnerability of the fiscal systems and financial crises, our estimation also attempt to control for the relevant political economy factors. These include the level of economic development and the institutional quality. We use GDP per capita as a measure of economic development and expect it to be decreasing with the use of financial repression revenue. To measure the institutional quality, we use the polity variable as well as the index of budgetary management, both of which should provide a proxy for the level of fiscal system efficiency and are negatively associated with the level of financial repression revenue in the data.

\subsection{Data}

We compile and update public debt data together with relevant controls across countries over the 1990s and 2000s. Following a seminal work of Giovannini and De Melo (1993), we base our calculation of the financial repression revenue on actual interest payments on foreign and domestic debts to derive the effective interest rate differentials. The appendix provides details of variable construction and data sources, which include the World Bank's Global Development Finance and World Development Indicators, the World Tax Database, the IMF's International Financial Statistics, and the Penn World Tables. Subject to data availability, we have a total of 62 countries in the whole sample, 24-45 countries in a restricted set of sample with detailed data from 1980 to 2000 for the estimation, and unrestricted set of 44 countries with sufficient data with at least 3 observation years of both the financial repression revenue and relevant controls for the panel estimation. In the restricted sample we calculated the financial repression revenue following closely the approach in Giovannini and De Melo (1993), whereas in the unrestricted sample we made a modification to the calculation in order to update the calculation with more recent figures subject to data availability, the details of which are described in the data appendix.

We conduct the analysis using both the restricted and the unrestricted subsamples for the following reasons. First, while the restricted sample covers only 1981-2000, the public debt data over this period are collected mostly and uniformly by the World Bank and therefore provide a consistent compilation of interest payment and debt stock across countries. Subsequently, the public debt data have been jointly compiled by World Bank, BIS, IMF, and OECD, which result in the changes of definitions and reports. Second, the restricted sub sample includes countries with detailed information on bilateral trade data as reported by the NBER-UN World Trade Flows project, essentially covers 1960-2000, that we use to construct the trade openness variable. Third, our unrestricted sample in the robustness check has updated the coverage of countries to 44 and years to 2009 , though this set of data may be subject to definition changes and different compilation processes as mentioned above.

\subsection{Baseline panel estimation}

Table 2 reports the baseline estimation using an unbalanced panel data accounting for country and year fixed effects, as well as common and country-specific time trend. The dependent variable is the financial repression revenue divided by GDP. The controls include trade openness, ${ }^{2}$ GDP per capita, and polity variable (measuring institutional quality by political durability). All the variables are in log to allow for non-linearities. Columns A-C provide the panel results for the full sample of 24 countries,

\footnotetext{
${ }^{2}$ As the governments may undertake trade, financial, and other major reforms simultaneously, the trade and financial variables would thus be endogenous to the country characteristics (e.g. GDP per capita and institutional quality), among a garden variety of macroeconomic consideration. We follow Frankel and Romer (1999) to use the gravity instrument for trade openness variable.
} 
Table 2

Baseline estimation. This table provides the panel and cross-country regressions. The financial repression revenue/GDP is calculated following Giovannini and De Melo (1993). Subject to data availability, the coverage is 1981-2000. The regressions are done using the OLS with fixed effects controls and all variables are in log. For cross-country regressions, the observations are weighted by the squared root of the number of years over which the observations are being averaged. Sub sample of countries with relatively high level of capital mobility are those at the second to fourth quartile of the capital mobility index (Edwards, 2007). Trade openness is measured first as gravity trade share (Frankel and Romer, 1999) and second as years since trade reform (Wacziarg and Welch, 2008). Standard errors are in parentheses, with ${ }^{* * *}\left({ }^{* * *},{ }^{*}\right)$ denotes statistical significance at $1(5,10)$ percent level.

\begin{tabular}{|c|c|c|c|c|c|c|c|}
\hline \multirow[t]{2}{*}{$\begin{array}{l}\text { Dependent variable: } \\
\text { financial repression } \\
\text { revenue/GDP }\end{array}$} & $\begin{array}{l}\text { Panel data, } \\
\text { full sample }\end{array}$ & $\begin{array}{l}\text { Panel data, } \\
\text { full sample }\end{array}$ & $\begin{array}{l}\text { Panel data, } \\
\text { full sample }\end{array}$ & $\begin{array}{l}\text { Sub sample of } \\
\text { countries with } \\
\text { high capital } \\
\text { mobility }\end{array}$ & $\begin{array}{l}\text { Sub sample of } \\
\text { countries with } \\
\text { high capital } \\
\text { mobility }\end{array}$ & $\begin{array}{l}\text { Cross-country } \\
\text { sample }\end{array}$ & $\begin{array}{l}\text { Cross-country } \\
\text { sample }\end{array}$ \\
\hline & A & B & C & $\mathrm{D}$ & $\mathrm{E}$ & $\mathrm{F}$ & G \\
\hline Trade openness, gravity instrumented & $\begin{array}{l}-.142 \\
{[.070]^{* *}}\end{array}$ & $\begin{array}{l}-.176 \\
{[.070]^{* *}}\end{array}$ & $\begin{array}{l}-.176 \\
{[.070]^{* *}}\end{array}$ & $\begin{array}{l}-.097 \\
{[.085]}\end{array}$ & $\begin{array}{l}-.096 \\
{[.084]}\end{array}$ & $\begin{array}{l}-.024 \\
{[.009]^{* * * * *}}\end{array}$ & \\
\hline Trade openness, years since trade reform & & & & & & & $\begin{array}{l}-.004 \\
{[.002]^{* *}}\end{array}$ \\
\hline GDP per capita & & $\begin{array}{l}-.213 \\
{[.095]^{* *}}\end{array}$ & $\begin{array}{l}-.217 \\
{[.095]^{* *}}\end{array}$ & $\begin{array}{l}-.326 \\
{[.149]^{* *}}\end{array}$ & $\begin{array}{l}-.324 \\
{[.148]^{* *}}\end{array}$ & $\begin{array}{l}-.041 \\
{[.015]^{* * * *}}\end{array}$ & $\begin{array}{l}.004 \\
.016]\end{array}$ \\
\hline Institutional quality, political durability & & $\begin{array}{l}-.052 \\
{[.048]}\end{array}$ & & $\begin{array}{l}.013 \\
{[.041]}\end{array}$ & & & \\
\hline$R^{2}$ & .538 & .554 & .553 & .839 & .842 & .146 & .100 \\
\hline Observations & 192 & 192 & 192 & 96 & 96 & 45 & 45 \\
\hline Countries & 24 & 24 & 24 & 19 & 19 & 45 & 45 \\
\hline Fixed effects controls & Yes & Yes & Yes & Yes & Yes & No & No \\
\hline Year & Yes & Yes & Yes & Yes & Yes & No & No \\
\hline Country & Yes & Yes & Yes & Yes & Yes & No & No \\
\hline Trend & Yes & Yes & Yes & Yes & Yes & No & No \\
\hline Country-trend & Yes & Yes & Yes & Yes & Yes & No & No \\
\hline
\end{tabular}


while columns D-E provide the results for the countries with relatively high level of capital mobility (i.e. second to fourth quartile of the capital mobility index, with the score above 60 out of 100 score). Columns $\mathrm{F}$ and $\mathrm{G}$ report cross-country estimation using alternative measures of trade openness.

The baseline regressions are able to account for $54-84 \%$ of variation in the financial repression revenue across countries, covering 1981-2000. As shown in columns A-C, with or without controlling for the GDP per capita and institutional quality, the trade openness variable is associated with a statistically significant drop in the financial repression revenue. The level of economic development captured in GDP per capita also has a negative and statistically significant association with the financial repression revenue. The association between institutional quality and financial repression revenue is also negative, but not statistically significant. The notion that countries with lower institutional quality tend to use 'easy-to-tax' financial repression revenue is therefore not supported in this set of regressions. By separately estimating on the subset of countries with high capital mobility in columns $\mathrm{D}$ and $\mathrm{E}$, we find that the negative association between the financial repression revenue and trade openness is potentially driven by a sub group of low capital mobility countries.

We then provide the regressions with alternative measures of trade openness and also conduct the estimation in the cross-country context. While trade openness is typically the importance of exports and imports in the economy (i.e. relative to GDP), alternatively trade openness may be a result of major policy shift and liberalisation of the commercialization across borders. We address this issue by estimating in a cross-country regression the financial repression revenue with not only the constructed trade share, but also the actual (exports+imports)/GDP as well as the number of years since a country's trade liberalisation. In a cross-country regression, as country-specific observations are averaged over a sample of different length, we therefore weigh the variables pertaining to each country with the square root of the number of years over which the country's average is computed. As shown in columns $\mathrm{F}$ and $\mathrm{G}$ of Table 2, across the 45 countries, our regressions are able to account for $10-14 \%$ of variation in the financial repression revenue across countries. We find that the negative association between trade openness and financial repression revenue is statistically significant, providing us further support that whether we use the de facto trade openness or the number of years since trade liberalisation, in the panel or cross-country context, the results remain consistent across the specifications.

To summarise the estimation of Table 2, Fig. 1 provides the economic significance of explanatory variables. We calculate the impact of a one standard deviation (+1s.d.) change of each explanatory variable on the financial repression revenue to GDP as the following. For the full panel sample of

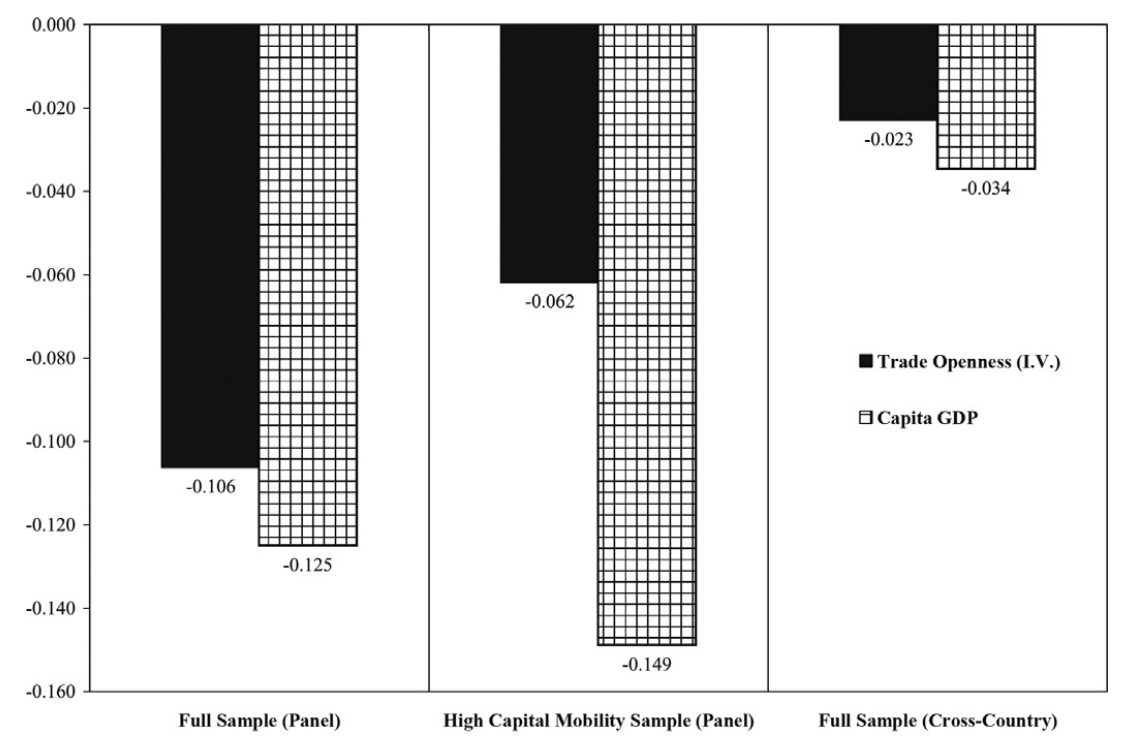

Fig. 1. The effect (\%) of one standard deviation change on the revenue from financial repression to GDP. Calculation is based on the estimation in Table 2. Each bar represents the product of the explanatory variable's estimated coefficient ( -0.176 for IV Trade Share on the financial repression revenue; Table 2 column C) and its standard deviation ( 0.60 for the log of IV Trade Share). Coefficients not statistically significant result in missing bars. 
Table 2, a standard deviation of log trade openness variable is .6; using the coefficient estimate of trade openness in column $C,-.176$, the effect of +1 s.d. increase of trade openness is associated with a reduction of financial repression revenue by $.6 \times[-.176]=-.106 \%$ of GDP as shown in the figure. To put the calculation in perspective, +1 s.d. change of trade openness is $22 \%$ (as of $1999,+1$ s.d. change of trade openness is equivalent to going from the level of Ecuador 56\% to the level of Israel 79\%); the effect of trade openness is approximately $-.1 \%$ on the financial repression revenue, thereby reducing the revenue from 4.0 to $3.9 \%$ of GDP $(4.0 \%$ of GDP is the mean financial repression revenue based on Table 1). Notably, in the full sample the effect of trade openness on the financial repression revenue/ GDP is $-.1 \%$, whereas the effect is $-.06 \%$ for a group of countries with high capital mobility. This suggests that a country with a low level of capital mobility would face an even greater fiscal challenge, having had its financial repression tax base being eroded more during its embracing of trade and financial globalization.

\subsection{Robustness}

We present in this section a robustness check to support the baseline results with more recent data as well as further exploring the drivers for the decline in the revenue from financial repression. Table 3 reports the panel data estimation, covering 44 countries from 1990 to 2009. In this unrestricted set of sample countries, we make certain that each country has at least 3 observation years so that the panel estimation can be applied suitably to the sample. Columns H-J report the panel estimation for the full sample of 44 countries, totaling 432 observations; columns K-M for the sub set of poor budgetary management countries (i.e. first and second quartile of the ranking scores); columns $\mathrm{N}-\mathrm{P}$ for the sub set of good budgetary management countries (i.e. third and fourth quartile of the ranking scores).

In essence, for Table 3 we allow for a horserace between trade openness and the financial openness in the regression, as well as a GDP per capita control. We also dissect the composition of financial repression revenue, using as the dependent variable in columns $\mathrm{H}, \mathrm{I}, \mathrm{J}$ : the foreign interest rate, the average interest rate, and the financial repression revenue/GDP. Due to data limitation, the financial repression revenue in Table 3 is not precisely the one in Table 2; whereas the interest rate differential is the effective foreign minus domestic interest rates in Table 2, the interest rate differential is the foreign minus average interest rates on the public debts in Table 3. Thus, the latter calculation provides an alternative approximation to the tax savings on interest payments similar to the standard calculation of Table 2 .

Based on the full sample of 44 countries, the fixed-effects estimation suggests that trade openness is negatively associated with the foreign interest rate (column $\mathrm{H}$ ); the financial openness is negatively associated with the average interest rate (column I); and overall, the financial openness is negatively associated with the financial repression revenue from 1990 to 2009 (column J). The association between GDP per capita and financial repression revenue is statistically insignificant. According to this set of estimation, it is therefore unclear whether trade openness or financial openness, or both that close the gap between foreign and domestic interest rates, and hence the revenue from financial repression.

Next, we split the sample into a group of countries with poor level of budgetary management and a group of countries with good level of budgetary management. In the former, we find that financial openness is negatively associated with the average interest rate (column L), resulting in a positive association between the financial openness and financial repression revenue/GDP (column M); thus countries with poor budgetary management facing the financial openness would tend to make a greater use of financial repression revenue. This could potentially be done by various forms of governmental control on the domestic interest rates, thereby lowering the cost of public debt management and imposing a financial repression tax internally on the domestic savings. On the other hand, for a group of countries with good budgetary management, we find that trade openness is negatively associated with foreign interest rate (column $\mathrm{N}$ ); financial openness is positively associated with the average interest rate (column $\mathrm{O}$ ); and the financial openness is negatively associated with the financial repression revenue/GDP (column P). Indeed, the overall explanatory power on the financial repression revenue is also largest for the group of countries with good budgetary management. It is thus in a set of good budgetary management countries that trade and financial openness together 
Table 3

Robustness check. This table provides the panel results updating Table 2 with more recent data. The modified financial repression revenue is calculated as described in the appendix. Subject to data availability, the coverage is 1990-2009. The regressions are done using the fixed-effects estimation and all variables are in level. Trade openness is measured the actual trade share for each country and year, calculated as exports plus imports, divided by gross domestic product. Financial openness is measured from the index of capital account openness, based on the IMF Annual Reports (Chinn and Ito, 2008). Sub sample of countries with relatively good level of budgetary management are those at the third and fourth quartile of the CPIA index. A constant term is included, but not reported. Standard errors are in parentheses.

\begin{tabular}{|c|c|c|c|c|c|c|c|c|c|}
\hline \multirow[t]{3}{*}{$\begin{array}{l}\text { Dependent variable: financial repression } \\
\text { revenue/GDP and components }\end{array}$} & \multicolumn{3}{|l|}{ Full sample } & \multicolumn{3}{|c|}{$\begin{array}{l}\text { Sub sample of countries with } \\
\text { poor budgetary management }\end{array}$} & \multicolumn{3}{|c|}{$\begin{array}{l}\text { Sub sample of countries with } \\
\text { good budgetary management }\end{array}$} \\
\hline & $\begin{array}{l}\text { Interest rate on } \\
\text { foreign debt }\end{array}$ & $\begin{array}{l}\text { Average } \\
\text { interest } \\
\text { rate }\end{array}$ & $\begin{array}{l}\text { Financial } \\
\text { repression } \\
\text { revenue/GDP }\end{array}$ & $\begin{array}{l}\text { Interest rate } \\
\text { on foreign } \\
\text { debt }\end{array}$ & $\begin{array}{l}\text { Average } \\
\text { interest } \\
\text { rate }\end{array}$ & $\begin{array}{l}\text { Financial } \\
\text { repression } \\
\text { revenue/GDP }\end{array}$ & $\begin{array}{l}\text { Interest rate } \\
\text { on foreign } \\
\text { debt }\end{array}$ & $\begin{array}{l}\text { Average } \\
\text { interest } \\
\text { rate }\end{array}$ & $\begin{array}{l}\text { Financial } \\
\text { repression } \\
\text { revenue/GDP }\end{array}$ \\
\hline & $\mathrm{H}$ & I & $\mathrm{J}$ & K & $\mathrm{L}$ & M & $\mathrm{N}$ & $\mathrm{O}$ & $\mathrm{P}$ \\
\hline Trade openness, actual trade share & $\begin{array}{l}-.012 \\
{[.006]^{* *}}\end{array}$ & $\begin{array}{l}.005 \\
{[.006]}\end{array}$ & $\begin{array}{l}-.024 \\
{[.020]}\end{array}$ & $\begin{array}{l}-.008 \\
{[.009]}\end{array}$ & $\begin{array}{l}-.002 \\
{[.008]}\end{array}$ & $\begin{array}{l}-.008 \\
{[.011]}\end{array}$ & $\begin{array}{l}-.015 \\
{[.007]^{* *}}\end{array}$ & $\begin{array}{l}.004 \\
{[.007]}\end{array}$ & $\begin{array}{l}.039 \\
{[.048]}\end{array}$ \\
\hline Financial openness & $\begin{array}{l}-.069 \\
{[.135]}\end{array}$ & $\begin{array}{l}-.219 \\
{[.124]^{\circ}}\end{array}$ & $\begin{array}{l}-2.626 \\
{[.431]^{* \ldots}}\end{array}$ & $\begin{array}{l}.106 \\
{[.229]}\end{array}$ & $\begin{array}{l}-.724 \\
{[.201]^{* * *}}\end{array}$ & $\begin{array}{l}.571 \\
{[.264]^{* *}}\end{array}$ & $\begin{array}{l}-.190 \\
{[.132]}\end{array}$ & $\begin{array}{l}.284 \\
{[.130]^{+*}}\end{array}$ & $\begin{array}{l}-6.099 \\
{[.855]^{*+*}}\end{array}$ \\
\hline GDP per capita & $\begin{array}{l}-.002 \\
{[.177]}\end{array}$ & $\begin{array}{l}-.230 \\
{[.162]}\end{array}$ & $\begin{array}{l}.271 \\
{[.567]}\end{array}$ & $\begin{array}{l}.171 \\
{[.298]}\end{array}$ & $\begin{array}{l}-.037 \\
{[.262]}\end{array}$ & $\begin{array}{l}.410 \\
{[.344]}\end{array}$ & $\begin{array}{l}-.132 \\
{[.168]}\end{array}$ & $\begin{array}{l}-.467 \\
{[.166]^{*+*+}}\end{array}$ & $\begin{array}{l}.137 \\
{[1.091]}\end{array}$ \\
\hline$R^{2}$ & .011 & .014 & .094 & .005 & .056 & .031 & .074 & .072 & .248 \\
\hline Observations & 432 & 432 & 432 & 249 & 249 & 249 & 183 & 183 & 183 \\
\hline Countries & 44 & 44 & 44 & 26 & 26 & 26 & 18 & 18 & 18 \\
\hline
\end{tabular}

"Denotes statistical significance at $10 \%$ level.

- Denotes statistical significance at $5 \%$ level.

Denotes statistical significance at $1 \%$ level. 
close the gap between foreign and domestic interest rates, and hence the use of financial repression revenue. ${ }^{3}$

To a certain degree, we can therefore draw a consistent conclusion from both the baseline estimation using the restricted set of data and the robustness estimation using the unrestricted sample with more recent data. Both trade and financial openness tend to force the governments into reducing the use of 'easy-to-tax' financial repression revenue as a part of public debt management. Because the process of trade and financial openness are mostly simultaneous with empirical linear feedbacks between the two, it is not clear which is the main driving factor on the decline of financial repression.

However, there is supportive evidence in the data that countries with good institutional quality and budgetary management are more likely to use less financial repression revenue. There are at least two channels that this can be accomplished. Firstly, a country could allow for more financial openness, more competition between domestically- and foreign-owned banks, thereby lowering overall volatility of lending and credit and pushing up the effective domestic interest rate more in line with the market signals; see Gerard Dages, Goldberg, and Kinney (2000). Secondly, by expanding international trade, a country could lower its vulnerability to the terms of trade fluctuation and sudden stop that link to the degree of external leverage of the absorption of tradable goods, thereby compressing the effective foreign interest rates on the public (and private) debt management; see Calvo, Izquierdo, and Loo-Kung (2006).

\section{Conclusion}

For developing countries, fiscal restructuring remains a challenge; a narrow tax base, weak tax collection effort, and frequent tax amnesties are among the symptoms of low institutional quality and poor budgetary management. This paper studies the association between trade and financial openness, and government revenue from financial repression empirically across countries. While we do not implicate on any normative assessment to which degree the economic integration is a favourable policy to embrace, the evidence suggests that financial integration is associated with a reduction of the financial repression revenue over the past two decades.

We find supportive evidence that countries, facing with the global trends of economic integration, may find it more difficult to resort to what was an 'easy-to-tax' government revenue from financial repression. While developing countries could potentially shift its revenue source away from the financial repression tax and possibly more towards the official taxation, the improvement of institutional quality and a good budgetary management are the necessary pre-conditions in the process. There remain other open questions at the intersection of public finance and international economics, including, for example, a further country-level study, as well as the association between sequential trade and financial opening in the presence of fiscal reforms.

\section{Appendix A. Data appendix A}

We use several data sources in the compilation of the financial repression revenue and relevant macroeconomic controls. These include the World Tax Database (WTD) from the Office of Tax Policy

\footnotetext{
${ }^{3}$ For countries with good budgetary management, the ministry of finance and monetary authority should refrain from borrowing at artificially low rates, be they notional or effective interests; this is supportive by the data presented. On the other hand, countries with poor budgetary management are forced upon by the impossible trinity (capital account openness, monetary independence, exchange rate stability): financial openness exposes poor macroeconomic management that inevitably affects the interest rate policy and exchange rate flexibility. One possibility is that the exogenous foreign interest rates influence the instability of domestic output, thereby reducing the effectiveness of risk sharing across borders, as well as raising the cost of direct tax revenue collection, and increasing the attractiveness of the financial repression revenue to the public sector in this group of countries. While accounting for the linkages across the impossible trinity convergence, public finance, and international trade is beyond the scope of the present study, we refer the readers Shambaugh and di Giovanni (2008) and Aizenman, Chinn, and Ito (forthcoming).
} 
Research, University of Michigan; World Development Indicators (WDI) and Global Development Finance (GDF) from the World Bank; the International Financial Statistics (IFS) from the IMF; Penn World Tables (PWT) from the University of Pennsylvania; and the NBER-UN World Trade Flows from the University of California, Davis.

Taxes: the total tax revenue to GDP and tariff revenue to GDP are calculated from the total tax revenue in local currency (WTD) divided by the GDP in local currency (WDI).

Exchange rates: we use the local currency per US dollar (IFS) to calculate the rate of currency depreciation.

Weighted tariff rate: the rate is in percent and compiled by the World Bank.

Financial repression revenue: we use two empirical approaches to calculate tax savings from the use of financial repression. Firstly, following Giovannini and De Melo (1993), the effective foreign interest rate is calculated from the foreign interest payment in US dollar (GDF) divided by the foreign debt outstanding in US dollar (GDF). The calculation of effective domestic interest rate is done similarly. The financial repression tax rate is the effective interest rate differential plus the rate of currency depreciation. The financial repression revenue to GDP is then calculated by multiplying the financial repression tax rate by the stock of domestic debt and divided by GDP. We use the financial repression revenue calculated by this first approach in the baseline regressions of Table 2. Secondly, in order to update with more recent numbers subject to data availability, we calculate the financial repression tax rate from the difference between the average interest rate on new official foreign debt commitments and the average rate of interest payments on the aggregate official debts. The financial repression revenue is calculated by multiplying this financial repression tax rate by the stock of public debt, and then divided by GDP. We use the financial repression revenue calculated by this second approach in the robustness regressions of Table 3.

Trade openness: the actual trade share is the exports plus imports divided GDP (NBER-UN, WDI). The number of years since trade reform is from Wacziarg and Welch (2008), based on changes in tariff and non-tariff barriers, black market premium, and the existence of export marking board and socialist government. The gravity-instrumented trade share is calculated following Frankel and Romer (1999), based on their data on bilateral distance, common borders and official languages, land area product, population of trading partners.

Financial openness: we use two indices of capital market integration; Edwards (2007) and Chinn and Ito (2008). The former is the index score on the degree of openness of the capital account in each country. The latter is based on the binary dummy variables that codify the tabulation of restrictions on cross-border financial transactions reported in the IMF's Annual Report on Exchange Arrangements and Exchange Restrictions (AREAER).

Institutional quality: we use two measures of institutional quality. The first is polity, which measures the political durability is from the POLITY IV project. The second is budgetary management, which is the CPIA quality index of budgetary and financial management rating ( $1=$ low to $6=$ high) from WDI.

Real GDP per capita: the figure is in PPP (constant 2005 international dollar) from WDI.

\section{Appendix B. Data appendix B}

This data appendix provides accompanying figures for the main analysis. The presentation is mainly done over the set of countries inclusive in the baseline regressions. For a further examination exclusively on a relationship between globalization and other types of taxation, see Aizenman and Jinjarak (2009).

Appendix Fig. 1 shows that the process of trade and financial openness go hand in hand, though they are not simultaneous. Following the criteria in Wacziarg and Welch (2008), we find that the level of financial openness (measured by the capital mobility index) tends to increase by approximately $40 \%$ following a major trade reform. The horizontal line shows the average level of capital mobility before and after the major trade reform for each country.

Appendix Fig. S2a and b shows trade and financial openness over the 1980s and 1990s across geographic regions, suggesting a global trend of the periods. Appendix Fig. S2c and d shows the 


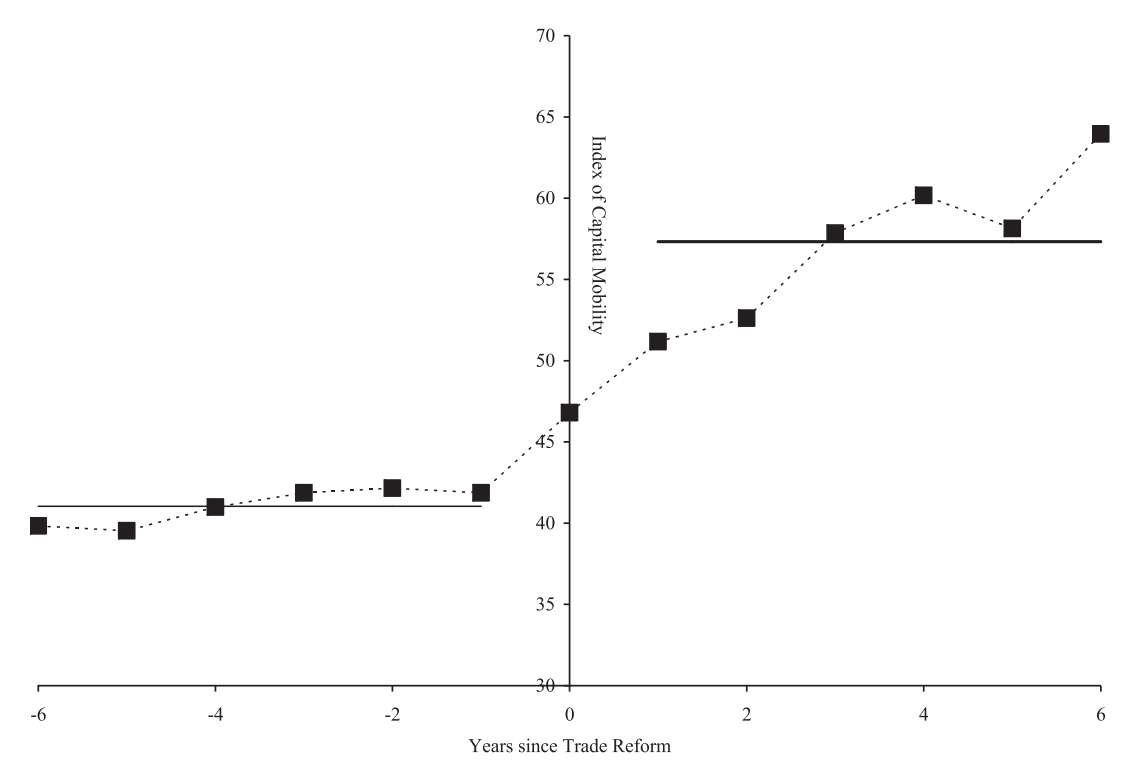

Appendix Fig. 1. de jure trade and financial integration.

decline in the tariff rates and inflation, suggesting that both declined in the 1990s by a greater extent in regions where they were above the average during the 1980s and thus converging towards a lower common level. As also discussed in Reinhart and Sbrancia (2011), public debt liquidation depends in a large part on the ability of government to engineer inflation. From the early 1980s to the late 1990s, inflation dropped from 8.84 to $2.20 \%$ for the group of high-income countries, from 10.19 to $7.48 \%$ for the group of middle-income countries, and from 10.20 to $7.66 \%$ for the group of low-income countries.

Appendix Fig. S3a reports the total tax collection/GDP of 22 countries with comprehensive data over the early 1980s (horizontally) and the late 1990s (vertically), whereby a further away is a country from the 45 degree line, the greater is the change of tax/GDP over the periods. We compare a 5-year average separated by ten years for the following reasons. First, a 5-year average should smooth variations associated with business cycles. Second, the cumulative effects associated with globalization should be more visible by comparing two sub periods separated by a period of time. Fig. S3b reports the government revenue from seigniorage (inflation tax) and tariff as a percentage of GDP, both of which traditionally are complementary to financial repression revenue (Giovannini and De Melo, 1993). As shown, the tax/GDP dropped from .182 to .176, the seigniorage and tariff to GDP dropped from .060 to .046. The quadratic fitted line allows for non linearity; the concavity of the cross-country pattern in Fig. S3b suggests that countries that relied heavily on the seigniorage and tariff revenue had confronted a greater loss; see also Aizenman and Jinjarak, 2009.

Appendix Figs. S4a and b reports together the 'easy-to-tax' revenues from seigniorage, tariff, and financial repression revenue. Notably is the non-linearity in the adjustment of financial repression revenue across the income groups.

Appendix Fig. S5a and b shows the difference between actual trade share and instrumental variable (IV) constructed trade share. The instrument is constructed from geographical determinants of bilateral trade, including log of distance, log of partner country population, log of area, dummy variables for common language, common land border, and landlocked status. After estimating the gravity model, we aggregate the exponent of the fitted values across bilateral trading partners to arrive at an estimate of total trade share for a given country.

\section{Appendix C. Supplementary data}

Supplementary data associated with this article can be found, in the online version, at http:// dx.doi.org/10.1016/j.ecosys.2012.10.003. 


\section{References}

Aizenman, J., 2004. Financial opening and development: evidence and policy controversies. AEA Papers and Proceedings 94 (2), 65-70.

Aizenman, J., 2008. On the hidden links between financial and trade opening. Journal of International Money and Finance 27 (April (3)), 372-386.

Aizenman, J., Chinn, M.D., Ito, H. The impossible trinity hypothesis in an era of global imbalances, Review of International Economics, forthcoming.

AizenmanF J., Jinjarak, Y., 2009. Globalisation and developing countries-a shrinking tax base? The Journal of Development Studies 45 (5), 653-671.

Aizenman, J., Ilan, N., 2006. FDI and trade-two-way linkages? The Quarterly Review of Economics and Finance 46 (July (3)), 317-337.

Calvo, G.A., Alejandro, I., Rudy, L.-K., 2006. Relative price volatility under sudden stops: the relevance of balance sheet effects. Journal of International Economics 69 (1), 231-254.

Chinn, M.D., Hiro, I., 2008. A new measure of financial openness. Journal of Comparative Policy Analysis 10 (3), 309-322.

Cukierman, A., Edwards, Sebastian, Guido, Tabellini, 1992. Seigniorage and political instability. The American Economic Review $82(3), 537-555$.

Demetriades, P.O., Luintel, K.B., 1997. The direct cost of financial repression: evidence from India. Review of Economics and Statistics 79 (2), 311-320.

Diaz Alejandro, C., 1985. Good bye financial repression, hello financial crash. Journal of Development Economics 19 (1), 1-24.

Dooley, M.P., 1996. A survey of literature on controls over international capital transactions. IMF Staff Papers 43 (4), 639-687.

Edwards, S., van Wijnbergen, S., 1986. The welfare effects of trade and capital market liberalization. International Economic Review 27 (1), 141-148.

Edwards, Sebastain. 2007, Capital controls, sudden stops, and current account reversals, in Capital Controls and Capital Flows in Emerging Economies: Policies, Practices and Consequences, Edwards, Sebastian, editor, University of Chicago Press, Chicago, chapter 2, pages 73-119.

Frankel, J.A., David, R., 1999. Does trade cause growth? American Economic Review 89 (3), 379-399.

Gerard Dages, B., Goldberg, L., Kinney, D., 2000. Foreign and domestic bank participation in emerging markets: lessons from Mexico and Argentina, Economic Policy Review, Federal Reserve Bank of New York, September, pp. 17-36.

Giovannini, A., De Melo, M., 1993. Government revenue from financial repression. American Economic Review 83 (4), $953-963$.

Kletzer, K.M., 2004. Liberalizing capital flows in India: financial repression, macroeconomic policy, and gradual reforms. India Policy Forum 1-34 (March).

Krueger, A.O., 1998. Why trade liberalization is good for growth. Economic Journal 108 (450), 1513-1522.

Reinhart, Carmen M., Sbrancia, M., Belen, 2011. The Liquidation of government debt, NBER Working Paper No. 16893, March.

Serven, L., Perry, G., 2005. Argentina's macroeconomic collapse: causes and lessons. In: Aizenman, J., Pinto, B. (Eds.), Managing Economic Volatility and Crises: A Practitioner's Guide. Cambridge University Press, New York, chapter 10, pp. 439-470.

Shambaugh, J., di Giovanni, J., 2008. The impact of foreign interest rates on the economy: the role of the exchange rate regime. Journal of International Economics 74 (2), 341-361.

Singh, A., Belaisch, A., Collyns, C., De Masi, P., Krieger, R., Meredith, G., Rennback, R., 2005. Stabilization and reform in Latin America: a macroeconomic perspective on the experience since the early 1990. IMF Occasional Paper, no. 238.

Wacziarg, R., Welch, K.H., 2008. Trade liberalization and growth: new evidence. World Bank Economic Review 22 (2), 187-231. 